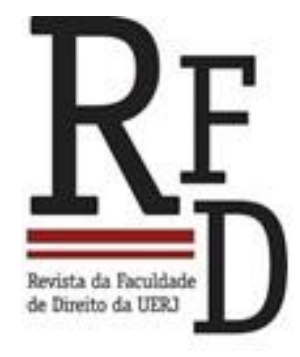

REVISTA DA FACULDADE DE DIREITO DA UERJ- RFD, N. 27, 2015

\title{
O ESTADO DEMOCRÁTICO DE DIREITO: A FUNDAMENTAÇÃO DAS DECISÕES JUDICIAIS COMO CONCRETIZAÇÃO DA CONTEMPORANEIDADE JURÍDICA
}

\begin{abstract}
THE DEMOCRATIC STATE OF LAW: THE REASONING OF THE JUDICIAL DECISIONS AS CONCRETION OF JURIDICAL CONTEMPORANEOUSNESS
\end{abstract}

Franchesco Maraschin de Freitas ${ }^{1}$

RESUMO: O devido processo legal é inerente ao Estado Democrático de Direito, sendo que sua criação se deu com a era do constitucionalismo. A ausência ou até mesmo a deficiência da fundamentação acarreta, ou deveria acarretar, a nulidade do ato jurídico pela ausência do devido processo legal. As decisões são responsáveis por transcrever aos olhos da sociedade se o processo judicial ou administrativo atenderam aos ditames do due process of law e se foi concretizado o direito ao acesso à justiça, ou seja, se o contraditório, a publicidade e a fundamentação foram contemplados pelo julgador.

Palavras-chaves: Devido processo legal. Fundamentação. Hard cases. Acesso à justiça. Estado Democrático de Direito.

ABSTRACT: The due process of law is inherent to the Democratic State of Law, being that its creation took place with the era of constitutionalism. The absence or even the lack of the substantiation involves, or should, the nullity of the juridical act by the absence of the due process of law. The decisions is responsible for transcribe to the eyes of society if the judicial our administrative process attended the dictates of the due process of law and if has been concretized the right of access to justice, in other words, if the contradictory, the publicity and the substantiation have been contemplated by the judge having the elements of the paradigmatic decision as reference.

Keywords: Due process of law. Substantiation. Paradigmatic decisions. Access to justice. Democratic State of Law.

\footnotetext{
${ }^{1}$ Mestrando do PPGD - Faculdade Meridional - IMED em Direito, Democracia e Sustentabilidade. Bolsista CAPES. Membro da Rede Brasileira Direito e Literatura (RDL). E-mail: freitas.franchesco@ gmail.com. Versão em português recebida em 03/12/2014, aceita em 21/04/2015, e autorizada para publicação em 29/06/2015 Versão em português recebida em 03/12/2014, aceita em 21/04/2015, e autorizada para publicação em 29/06/2015
} 


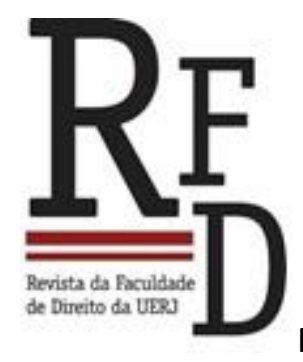

REVISTA DA FACULDADE DE DIREITO DA UERJ- RFD, N. 27, 2015

\section{INTRODUÇÃO}

O conceito de que o Direito corresponde ao produto da legislação está superada pelo reconhecimento da importância do Poder Judiciário como órgão concretizador e garantidor de direitos.

Por ser o Poder Judiciário o órgão responsável pela aplicação da legislação e instituição indispensável para solidificação do autêntico regime democrático de direito, deve ele agir com total transparência e clareza. Logo, quando o judiciário se manifesta através de suas decisões, entende-se que elas devem explicitar os motivos fáticos e jurídicos que lhe dão suporte, para que não só as partes litigantes, mas sim toda a sociedade possa se valer dos direitos do acesso à justiça.

Não seria justo se um indivíduo tivesse um direito seu restringido e não tivesse acesso ao por que da restrição. Por isso, a sentença corretamente fundamentada tem a característica de tornar límpido à sociedade o direito que ela pode esperar, sendo a sentença o instrumento legal que o prolator da decisão irá fundamentar tudo que lhe foi evidenciado e provado no decorrer do processo, mesmo quando tratar-se dos (supostos) hard cases.

Se a sentença não for devidamente fundamentada e o resultado for contrário aos interesses da parte, como poderia ela recorrer sem saber, ao certo, em que razões se fundam a decisão e se elas estão de acordo com o direito. Desta forma, a fundamentação das sentenças é elemento essencial para reclamar o direito em instância superior, devendo ser completa, atingindo todos os pontos articulados na lide, para que o recurso seja o mais específico possível, e também, para que não seja violado o princípio do devido processo legal enquadrado no artigo 5º LIV da Constituição Federal de 1988.

\section{A constante superação do positivismo pelo constitucionalismo}

Para concretizar um modelo efetivamente democrático se faz necessário ultrapassar algumas barreiras impostas pelo positivismo ao constitucionalismo, eis que essa noção jurídica reclama a revisão de elementos jurídicos que poderiam implicar na oposição a um Versão em português recebida em 03/12/2014, aceita em 21/04/2015, e autorizada para publicação em 29/06/2015 


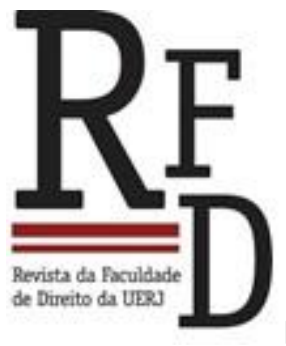

REVISTA DA FACULDADE DE DIREITO DA UERJ- RFD, N. 27, 2015

modelo considerado democrático de direito. Lênio Streck relaciona, de forma sistemática, os contrapontos existentes entre:

a) Norma em vez de valor; b) subsunção em vez de ponderação; c) independência do direito ordinário em vez de onipresença da Constituição; d) autonomia do legislador democrático dentro do marco da Constituição em vez de onipotência judicial apoiada na Constituição (STRECK, 2005, p. 159).

No campo do direito, atualmente, há uma grande confusão no que diz respeito aos vários tipos de positivismo. Existe, de forma retórica, o positivismo exegético, o qual afirma que há uma proibição de interpretar o texto de lei, que separa direito e moral, texto e norma. De outro lado, há o positivismo normativista, que relega o problema da interpretação jurídica a uma "questão menor", afirmando que esse problema é muito mais semântico do que sintático. Lênio Streck, em sua obra, questiona as correntes positivistas existentes argumentando que obedecer à risca o texto da lei democraticamente constituída não guarda relação com a exegese positivista, à moda antiga. Nesse caso a moral fica de mora de qualquer decisão; agora, no Estado Democrático de Direito, ela é co-originária (STRECK, 2006, p. 86).

A posição positivista exegética deixa a desejar, vez que, para os que defendem essa corrente, uma norma vale mais que um valor constitucional. Apesar do positivismo ter influenciado e ter sido importante em certo contexto histórico, o seu segmento, que é formalista, seria de nítido caráter retórico. As características de não admitir lacunas, de não reconhecer princípios como normas, de ter dificuldades em explicar os conceitos indeterminados, faz a legalidade ocupar o lugar que deveria ser da legitimidade do direito.

A crítica exposta reside no fato de que o juiz pode decidir por valores éticos e de forma axiológica no que tange o caso fático-temporal, contanto que ele não se "transforme" em legislador, criando novos direitos e decidindo única e exclusivamente por seu senso (STRECK, 2016, p. 94), qual é o caso do positivismo normativista de Hans Kelsen. A superação das barreiras supracitadas proporcionou o descarte do paradigma positivista, o qual ocorreu em três frentes. 


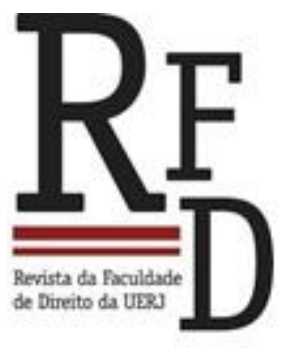

REVISTA DA FACULDADE DE DIREITO DA UERJ- RFD, N. 27, 2015

Primeiramente, ocorreu pela teoria das fontes, visto que a lei já não é mais a única fonte de Direito, aparecendo a Constituição como ponto de partida, como auto aplicativa; em segundo lugar ocorreu alteração da teoria da norma, tendo em vista o aparecimento dos princípios (cuja guarda relação com a teoria das fontes); e por último, dá-se frente o plano da interpretação, em que toda decisão, judicial ou administrativa, deve partir referente aos princípios constitucionais (STRECK, 2004, p. 325).

A teoria das fontes tem o ideal de a Constituição Federal ser a origem de validade de Direito, na qual todas as outras leis são subordinadas a ela, não só as leis, mas também, as decisões judiciais, os atos administrativos, a doutrinas e a jurisprudência.

A teoria da norma diz respeito à confecção das regras, como textos, fundadas em princípio que devem reger o Estado Democrático de Direito. Pode-se entender que os princípios constitucionais são a base para o legislador criar leis que possam dar diretrizes ao Estado Constitucional.

O plano de interpretação dá-se na reflexão de texto e norma, pois só há norma se interpretado o texto, fundado nos princípios que regem o ordenamento jurídico. Ademais, é a partir dos princípios constitucionais que o julgador deve se basear para interpretar a lei, e não conforme sua consciência.

A "superação" do positivismo parte do surgimento do Estado Constitucional e da "reisenserção da moral no direito" (STRECK, 2014, p. 239), com o denominado (neo)constitucionalismo, ou, constitucionalismo jurídico - nas palavras de Ferrajoli o termo neoconstitucionalismo, sob vários aspectos, possui uma terminologia ambígua e enganadora. Existe uma larga distinção entre ambas, sendo que o primeiro defende que ocorreu uma superação em sentido tendencialmente jusnaturalista do positivismo jurídico (léxico político), e o segundo considera o constitucionalismo a expansão e complemento do positivismo jurídico (léxico jurídico) (FERRAJOLI, 2012, p. 15) -, instituídos pelas cartas políticas promulgadas após a Segunda Guerra Mundial.

Para Lênio Streck, o termo neoconstitucionalismo também é capitulado com um viés errôneo (visto que poderá conduzir à jurisprudência da valoração e suas derivações 


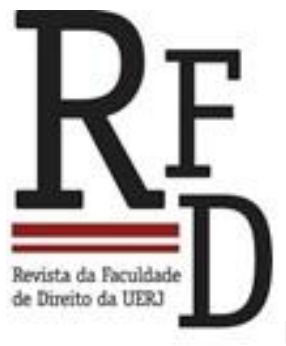

REVISTA DA FACULDADE DE DIREITO DA UERJ- RFD, N. 27, 2015

axiológicas), no qual o autor concorda com Ferrajoli, contudo, usa a titulação de Constitucionalismo Contemporâneo, pois essa terminologia conduz a um processo de continuidade com novas conquistas, as quais passam a integrar a Estrutura Constitucional póssegunda guerra (STRECK, 2014, p. 47).

Vê-se que nesse novo contexto cabe ao Poder Judiciário garantir os direitos fundamentais e preservar o regime democrático, em outras palavras, assegurar o devido processo legal (TRINDADE, 2012, p. 96/97), sempre tendo em seu contexto a Constituição como arrimo.

As três frentes estão correlacionadas entre si, visto que uma leva a outra. A teoria das fontes relaciona-se com a teoria das normas frente que as leis são confeccionadas a partir dos princípios que estão intrínsecos na sociedade e a aplicação das mesmas se dá pela teoria da interpretação. Por conseguinte, não existe uma sem a outra, e não existe Estado Constitucional sem as três.

Destarte, a real superação do positivismo se dá, apenas, se conseguirmos enfrentar seu maior problema prático: a discricionariedade judicial. "O direito é composto por regras e princípios, 'comandados' por uma Constituição" (STRECK, 2010, p. 95), todavia, esses princípios devem ser concebidos em conjunto, com a função de estabelecer padrões hermenêuticos e com o fito de preservar a autonomia do direito; estabelecer condições hermenêuticas para controlar a interpretação constitucional; garantir a integridade do direito posto; impor a fundamentação coerente das decisões judiciais como dever fundamental do julgador e garantir que cada cidadão tenha seu litígio julgado de acordo com o devido processo legal (STRECK, 2010, p. 96).

Considera-se um direito fundamental processual o devido processo legal, ponto em que chega a ser inerente ao Estado Constitucional a sua existência. Ao que pese também, a doutrina faz conexão entre os princípios do contraditório, da fundamentação e o direito ao processo justo. Guilherme Marinoni (2012, p. 666) aprofunda essa ideia, pois sem fundamentação a decisão judicial perde duas características centrais: a justificação da norma 


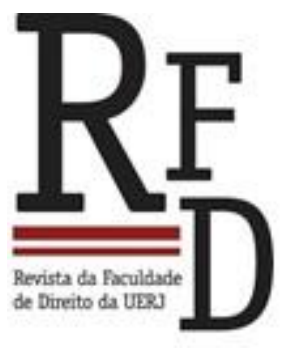

REVISTA DA FACULDADE DE DIREITO DA UERJ- RFD, N. 27, 2015

jurisdicional para o caso concreto e a capacidade de orientação de condutas sociais. Perde, em uma palavra, o seu próprio caráter jurisdicional.

\section{0 devido processo legal como princípio paradigmático}

O Estado Constitucional proporciona que o próprio Estado observe alguns deveres e princípios essenciais para caracterizar um regime democrático de direito. Deveres esses, que nada mais são que a possibilidade de assegurar um governo democrático e controlar a discricionariedade do Poder Público.

A discricionariedade do Poder Público é controlada por um princípio em específico, o princípio do devido processo, estabelecido de modo expresso, pela primeira vez em nosso ordenamento jurídico, na Constituição de 1988 no artigo 5, LIV, que trata que "ninguém será privado da liberdade ou de seus bens sem o devido processo legal”.

O princípio do devido processo legal - que é o princípio base sobre a qual todos os outros se sustentam - é oriundo da expressão inglesa due process of law, consagrado no reinado de Eduardo III, em 1354, na lei denominada Statute of Westminster of the Liberties of London, por meio de um legislador desconhecido (NERY JR, 2002, p. 33).

No seu sentido genérico, o princípio do devido processo legal caracteriza-se pelo trinômio vida-liberdade-propriedade, correspondendo a tudo o que disser respeito à tutela desse trinômio está sob a proteção do due process of law, ou seja, a liberdade de opinião, de imprensa, de religião, a privacidade, a liberdade de escolha, a deliberação dos bens particulares estão relacionados com o princípio em questão (NERY JR., 2002, p. 35).O devido processo, pois, pode ser deduzido do "conjunto de princípios de uma ordem constitucional fundada na legalidade e na proteção das liberdades” (MENDES, 2013, p. 1324).

Quando instituído no ordenamento inglês, o due process of law ressaltava apenas o sentido eminentemente processualístico, sendo, no decorrer dos anos, pela doutrina e jurisprudências, alargado ao âmbito dos direitos fundamentais dos cidadãos, permitindo uma interpretação elástica (MENDES, 2013, p. 37). Nas palavras de Nelson Nery Junior (2002, p. 


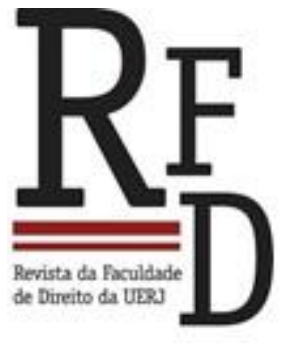

REVISTA DA FACULDADE DE DIREITO DA UERJ- RFD, N. 27, 2015

37), "a origem do subtantive due process teve lugar justamente com o exame da questão dos limites do poder governamental, submetida à apreciação da Suprema Corte norte-americana no final do século XVIII".

Por se tratar de um princípio aberto, que cria uma superafetação da nossa Constituição, onde costumeiramente se faz referência direta ao devido processo legal em lugar de se referir a uma das garantias específicas, Gilmar Gilmar Mendes (2012, pag. 385) posiciona que o princípio do devido processo legal possui um âmbito de proteção amplo, cujo exige o Fair Trial não apenas dos sujeitos que fazem parte da relação processual, ou dos atuam de forma direta no processo, mas sim, de todo o crivo jurisdicional - instituições, órgãos públicos e privados, sujeitos -, ou seja, que possuem funções qualificadas, constitucionalmente, como essenciais à Justiça.

Conforme salienta Paulo Bonavides, o princípio do devido processo legal faz possibilitar que todo ato injusto e arbitrário poderá ser considerado inconstitucional (BONAVIDES, 2000, p. 388). Nesse raciocínio também podemos elencar não só o artigo $5^{\circ}$, LIV, da Constituição Federal como o detentor do princípio do devido processo legal, mas também, o artigo $3^{\circ}$, I, da própria Constituição, que taxa em seu teor uma sociedade justa como objetivo fundamental do nosso país: "constituem objetivos fundamentais da República Federativa do Brasil: I - construir uma sociedade livre, justa e solidária”.

A conclusão é obtida pela interpretação da palavra "justa”. Se a justiça é um objetivo de toda a República Federativa do Brasil, obrigatoriamente deve ser um objetivo do Poder Público em geral, ou seja, o devido processo legal substantivo deve estar presente em todos os atos do Poder Judicial.

Para tanto, deve-se compreender o sentido de devido processo legal. Ele pode ser considerado em duas percepções: formal e substantivo. A expressão formal, também conhecida como processual, alcança um sentido restrito de due process of law, nada mais sendo que a possibilidade efetiva de a parte ter acesso à justiça, deduzindo pretensão e podendo se defender do modo mais amplo possível (NERY JR., 2002, p. 42). O formal trata da perspectiva que os direitos fundamentais só podem ser exigidos e respeitados nas vias 
processuais. J. J. Canotilho (1997, p. 494) afirma que o devido processo legal formal limita-se a concretizar que quando uma pessoa é privada dos seus direitos fundamentais, tais como à vida, liberdade e à propriedade, essa tem o direito de exigir que essa privação seja efetuada segundo o processo específico escudado pela lei, ou seja, a questão está estritamente relacionada com o dever de observância ou não do processo criado por lei.

Em contrapartida, o devido processo legal substantivo traz em si o ideal de justiça, não apenas um processo legal, mas, sobretudo um processo legal, justo e adequado, em que, às autoridades judiciais deve ser vedado o direito de disporem arbitrariamente dos direitos fundamentais, ou seja, os juízes poderiam, baseados nos princípios constitucionais de justiça, analisar os requisitos intrínsecos da lei (CANOTILHO, 1997, 495).

Argumenta Moura que no ordenamento jurídico brasileiro o devido processo legal substantivo possui o componente material, na medida em que declara que o devido processo legal é assegurado às partes em todos os processos judiciais (MOURA, 2000, p. 77).

Existe decisão do ex Ministro do Supremo Tribunal Federal, Carlos Velloso (1996, ADI - 1511 - MC/DF), que entende existir o conteúdo substantivo no devido processo legal:

Due process f law, com conteúdo substantivo - substantive due process - constitui
limite ao Legislativo, no sentido de que as leis devem ser elaboradas com justiça,
devem ser dotadas de razoabilidade (reasonableness) e de racionalidade
(rationality), devem guardar, segundo $\mathrm{W}$. Holmes, um real e substancial nexo com o
objetivo que se quer atingir. Paralelamente, due processo of law, com caráter
processual - procedural due process - garante às pessoas um procedimento judicial
justo, com direito de defesa.

A fundamentação judicial está intrínseca ao devido processo legal substantivo, visto que se manifesta em todos os campos do direito, em seu aspecto substancial (NERY JR., 2002, p. 38), pois não há devido processo legal se a decisão que estabelece uma obrigação ou priva um cidadão de sua liberdade, ou de algum bem seu, não observar a fundamentação adequada.

Para uma decisão ser adequada, ela necessita ser racionalmente justificada, baseandose em argumentações racionais e legítimas, sendo essa exigência um dever que deve ser estendido a todos os casos em que os juristas argumentam. Como aduz Alexy, "da Versão em português recebida em 03/12/2014, aceita em 21/04/2015, e autorizada para publicação em 29/06/2015 


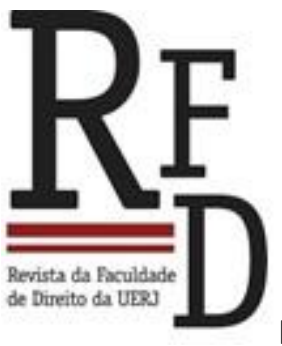

REVISTA DA FACULDADE DE DIREITO DA UERJ- RFD, N. 27, 2015

possibilidade de uma argumentação jurídica racional dependem não só o caráter científico da Ciência do Direito, mas também a legitimidade das decisões judiciais" (ALEXY, 2005, p. 35). Portanto, não basta que a decisão seja fundamentada, contendo apenas um mérito injustificado ao caso em lide, mas sim, deve conter uma fundamentação amparada de racionalidade com o pleito em tela.

Para dar robustez ao estudo, Guilherme Marinoni (2011, p. 458/459) afirma que "a fundamentação da sentença tem de apresentar coerência lógica e contextual, importando aí os nexos do direito como um todo e do senso comum articulados no âmbito da motivação". Para tanto, a coerência lógica é fundamental para validade da decisão proferida.

Assim, o devido processo legal exigiria que a decisão judicial fosse devidamente adequada, o que, pragmaticamente, implicaria na sua fundamentação racional como elemento que lhe emprestaria legitimidade, além de servir como instrumento jurídico de controle do arbítrio e da discricionariedade político-jurídico.

\section{Easy Cases e Hard Cases. Existem?}

Fundamentar a fundamentação é o elemento hermenêutico pelo qual se manifesta a compreensão do fenômeno jurídico (STRECK e OLIVEIRA, 2012, p. 99), por isso é necessário que a fundamentação da decisão judicial seja a mais completa e de acordo com a Constituição possível. Os (considerados) casos difíceis (hard cases) são circunstâncias que demandam maior atenção dos estudiosos do Direito, pois são neles que possivelmente haverá um elevado grau de discricionariedade por parte dos juízes.

No ideário de Carl Schmitt (jurista engajado nas causas nacional-socialistas da época da Alemanha nazista), tido como um adversário veemente da democracia liberal, a discricionariedade seria defendida pelo poder absoluto do Führer, não podendo haver nenhuma norma de "princípio de condução" ou uma "supervisão" as suas decisões, pois nenhuma restrição de tipo "normativista" deveria impossibilitar a ação soberana do Führer, e nenhuma intromissão "de baixo" deveria alterar seu poder discricionário (SCHMITT, 1995, p. 
230). A ação do Führer "não se submete à justiça, mas ela seria, ela mesma, a justiça suprema" (SCHMITT, 1934, p. 200). Ou seja, na visão contrária à democracia, a discricionariedade não seria "privilégio" do judiciário, mas sim, estaríamos regredindo à época feudal. [Comentário: Maior desenvolvimento da discussão da metodologia, como sugerido SNB2].

No positivismo jurídico exegético - qual já foi superado por completo, conforme já demostrado alhures - havia a impossibilidade de que os juízes decidissem algum fatídico se não de acordo exclusivamente pelas leis, pois "tudo" estava regulamentado, inexistindo lacuna que não pudesse ser suprida pela aplicação da lei.

Para Hans Kelsen, denominado "pai do positivismo normativista", haveria condições em que o caso concreto seria complicado demais para ser enquadrado em leis, sendo considerados "casos difíceis". Para tanto, o julgamento desses casos deveria partir da análise da teoria dos casos difíceis, ou seja, quando uma ação específica não fosse contemplada pelas regras postas, ou não existisse regra clara para sua aplicação, o juiz teria o "poder discricionário" para decidir o caso de uma maneira ou de outra (DWORKIN, 2010, p. 126).

Esse poder discricionário de decidir, para Hans Kelsen, seria fundamentado no resultado do conhecimento do julgador, visto não se tratar de um problema de teoria do Direito, mas de um problema de política do Direito. Entende-se que o aplicador do Direito, assim como o legislador, é passível, na hora da efetivação de suas tarefas, de usarem da vontade, mantendo-se, contudo, dentro da moldura do quadro geral (KELSEN, 1988, p. 393).

Portanto, na visão kelsiana, é através de uma interpretação autêntica (feito por um órgão aplicador de direito e aplicada a todos os casos semelhantes, como se fosse lei) que pode criar-se Direito para decidir os casos difíceis, como, por exemplo: jurisprudência de tribunal superior (KELSEN, 1988, p. 394).

Na visão de Hebert H. Hart, as normas podem possuir uma textura aberta, impedindo que o direito se expresse através de enunciados unívocos, ou seja, para abranger o maior número de objetos é possível empregar palavras abstratas e genéricas, mas isso causa vagueza e ambiguidade dos significados aumentando a indeterminação que se pretendia controlar, 


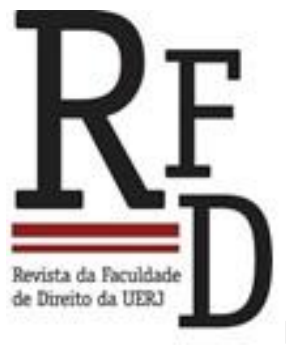

REVISTA DA FACULDADE DE DIREITO DA UERJ- RFD, N. 27, 2015

gerando a necessidade do intérprete buscar a complementação de significados dos termos não claros.

A determinação dessa textura aberta ocorre no campo do direito por meio da interpretação jurídica, logo, se todas as regras jurídicas se manifestam por meio da linguagem natural, todas as regras jurídicas precisam ser interpretadas, porém, não há nenhuma regra capaz de controlar essa interpretação, isso significa que, dentro da vida prática, a determinação do direito pode ser feita por aqueles que interpretam as regras em ultima instância, ou seja, os juízes (que possuem forte poder discricionário para interpretar as regras).

H. Hart, quando trata da caracterização pela textura aberta, está a falar, exclusivamente, na interpretação dos casos difíceis, nos quais a indeterminação do sentido das regras seria insolúvel, dando aos intérpretes (julgadores) poderes discricionários de decisão, permitindo a criação de novas regras para o julgamento do caso em lide - nos casos tratados como paradigmas, o julgador recorreria às regras jurídicas institucionalizadas (ROCHA, 1997, p. 26).

Para H. Hart (1994, p. 141), responsável pela inserção do paradigma hermenêutico na análise do direito, o preenchimento da zona de penumbra das regras (teoria da textura aberta) fica à livre escolha dos intérpretes, e o único limite pra interpretação seria o bom senso.

Na tentativa de solucionar o problema da discricionariedade judicial, Ronald Ronald Dworkin (2010, p.127), um dos mais conhecidos críticos de H. Hart, formula sua teoria para solucionar os casos difíceis, na qual consiste que o juiz, mesmo em tais casos, continua tendo o dever de desvelar quais são os direitos das partes, e não "inventar" novos direitos para aplicação retroativa, devendo, portanto, ser o menos original possível.

Diferentemente de H. Hart - em que a discordância dos juízes seria, somente, uma discordância de teor linguístico, e que uma regra poderia ser aplicada em várias situações -, Ronald Dworkin tem a concepção de regra como "tudo ou nada", em que quando a um conflito entre ambas a que for a melhor possível invalidaria outra (KARAM DE CHUEIRI, 1997, p. 171). 


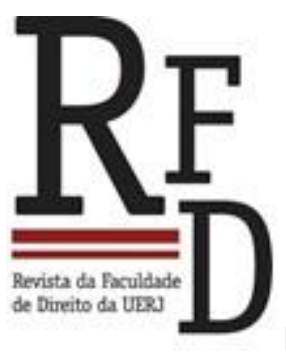

REVISTA DA FACULDADE DE DIREITO DA UERJ- RFD, N. 27, 2015

Referente à possibilidade de uma resposta certa para o fatídico, H. Hart aduz que não existe resposta certa, haja vista o sistema jurídico ser dotado de imprecisão linguística, tornando-se um sistema aberto, relativamente às lacunas existentes no direito. Na teoria hartiana, essa inexistência de resposta certa a pretensão de um direito prescinde o poder discricionário do juiz de criar direito. Ronald Dworkin, crítico veemente do de H. Hart, partindo do dito supra, formula a chamada "tese da resposta da certa" (KARAM DE CHUEIRI, 1997, p. 173).

Contudo, alega que não existe uma mecanização para tal solução, sendo que os juízes divergirão frequentemente sobre os direitos jurídicos, de igual forma que os homens de Estado divergem sobre os direitos políticos (KARAM DE CHUEIRI, 1997, p. 126). Entretanto, conforme próprio Ronald Dworkin alerta, só se pode discutir quantos livros tem na prateira se chegarmos no consenso do que é um livro.

O uso dos princípios, na concepção de Ronald Dworkin, possui dois níveis: internamente em oposição à de política e externamente em oposição à regra jurídica. $\mathrm{O}$ primeiro caso diz respeito que toda decisão judicial pautada em princípios atende a questão peculiar do caso em apreço, mas se o mesmo for baseado em políticas, atenderá a um fim coletivo, tendo em vista o bem-estar geral da comunidade. É na atividade judicial que o binômio princípios/política ganha relevância ao determinar a compreensão e consecução de uma nova teoria das decisões judiciais, a qual constrói um espaço democrático de interação entre a filosofia, a política e o direito (KARAM DE CHUEIRI, 1997, p. 158).

Para Ronald Dworkin, o julgador ao se deparar um suposto caso difícil deve se socorrer dos princípios que regem aquela sociedade e aquele sistema legal, caso em que deverá descobrir - sozinho - o direito do caso. Propõe, para tanto, uma teoria que afirma a necessidade de correlação entre direito, princípios, moral, política e até mesmo economia para a solução do hard case, ao ponto de descobrir o direito que "estava oculto" dentro do caso concreto (ROCHA, 1997, p. 26). Os indivíduos teriam direito à aplicação consistente dos princípios sobre os quais se assentam as suas instituições, ou seja, na sua teoria o juiz deve 


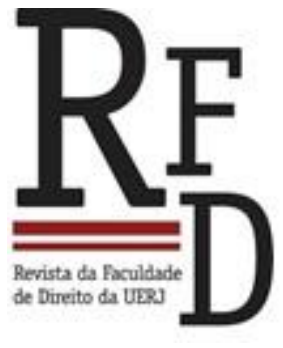

REVISTA DA FACULDADE DE DIREITO DA UERJ- RFD, N. 27, 2015

identificar uma concepção particular de "moralidade comunitária" como fator resolúvel dos litígios daquela comunidade (DWORKIN, 2010, 197).

A criação de novos direitos retroativos, conforme defende H. Hart, é uma maneira viciosa de ferir o princípio da legalidade, já que a irretroatividade do direito ameaçaria a segurança jurídica da democracia (ROCHA, 1997, p. 26).

Alexy considera, diferentemente de Ronald Dworkin, que não existe uma única resposta no direito que se enquadraria no caso concreto, mas sim, podem existir várias respostas - quais, nesse caso, são conhecidos como "casos de colisão" -, cujas seriam solucionadas pela técnica da ponderação entre os princípios constitucionais.

No pensamento alexyano, quando o juiz toma uma decisão que não pode ser amparada exclusivamente pela solidificação normativa ou não possa fundamentar definitivamente a decisão com a ajuda das regras da metodologia jurídica, então resta ao intérprete aplicador um campo de escolhas entre várias soluções, "a partir de normas jurídicas, regras metodológicas e enunciados de sistemas jurídicos não determinados ulteriormente” (ALEXY, 2013, p. 23), qual deverá partir do seu juízo de valor.

Esse campo de escolha - oriundo dos casos de colisão -, como dito alhures, deverá passar pelo crivo dos princípios e da moral (a moral deixa de ser autônoma, conforme aduzia Hans Kelsen, e passa a ser cooriginária ao direito (STRECK, 2014, 236)), pelo âmbito da facticidade do caso em apreço. Os princípios, diferentemente do que ocorria no positivismo, passam a compor um novo Estado, um direito que passa a cuidar mais do mundo prático e não apenas de um modelo de regras.

O maior problema na teoria argumentativa de Alexy, na visão de Lênio Streck, é que essa não resolve a mantença de um julgador solipsista - visto a não contemplação do giro ontológico-linguístico (superação do modelo sujeito-objeto) -, dando "poderes" discricionários para que o juiz escolha a "melhor decisão ao caso" partindo da ponderação, ou seja, uma escolha subjetiva (STRECK, 2014, 241). Essa é uma conclusão admitida pelo próprio Alexy no posfácio de seu livro Teoria dos Direitos Fundamentais quando admite que os direitos fundamentais não sejam objetos de passível divisão de forma refinada, existindo 
uma discricionariedade, tanto legislativa quanto judicial, para o sopesamento (ALEXY, 2008, 611). Eis aqui, portanto, a ímpar diferença entre a teoria da argumentação alexyana e a hermenêutica: enquanto a argumentação usa dos princípios como uma abertura interpretativa (princípios como mandados de otimização), a hermenêutica parte do pressuposto que os princípios introduzem o mundo prático do direito, fechando a interpretação, ou seja, diminuindo o nível de discricionariedade do intérprete (STRECK, 2014, p. 245). Para a hermenêutica a resposta correta não seria dada a partir da ponderação do juiz, mas, sim, da “construção principiológica do caso" (STRECK, 2014, p. 249).

É a partir da hermenêutica que se chega à conclusão de que não deve haver diferenciação estrutural entre os hard cases (ponderação) e easy cases (subsunção), visto que a problemática dos princípios é de cunho hermenêutico (compreensão), e não analíticoprocedimental (fundamentação) STRECK, 2013, p. 308). Na visão hermenêutica, não há distinção entre hard/easy cases, "essa distinção [...] desaparece em face do círculo hermenêutico e da diferença ontológica" (STRECK, 2013, p. 309), ou seja, a teoria argumentativa leva em conta a existência de um pré-compreender antecipador, operações causais-explicativas (tanto nos supostos casos fáceis quanto nos casos difíceis, partindo do ponto que já existe uma hierarquização dos princípios), quando a hermenêutica leva em conta, corretamente, a compreensão fática. A dicotomia enraíza o direito naquilo que o Constitucionalismo Contemporâneo combate: o esquema sujeito-objeto.

Caso houvesse tal distinção, não estaríamos remando no velho silogismo? Ou, ainda, a ponderação não seria uma subsunção de segundo grau? No final do andor, para teoria da argumentação tudo acaba em subsunção, visto que, no Brasil, a proporcionalidade acaba sendo aplicada como regra, e não como princípio (STRECK, 2010, p. 54). A pergunta "o que devo fazer" (solipsismo) deve ser substituída pela pergunta “o que se deve fazer”? (STRECK, 2014, p. 308).

\section{A fundamentação das decisões judiciais como fator elementar do Estado Democrático de Direito.}

Versão em português recebida em 03/12/2014, aceita em 21/04/2015, e autorizada para publicação em 29/06/2015 
Primeiramente, adequada, desde já, a colocação de Lênio Streck no que tange a fundamentação das decisões judicias quando preconiza que "o Estado Democrático de Direito exige fundamentação detalhada de qualquer decisão" (STRECK, 2014, p. 250). Parte-se do pressuposto de que a decisão judicial somente atende ao devido processo legal substancial se adequada ao contexto e à lógica do processo, ou seja, racionalmente fundamentada (ALEXY, 2005, p. 05). Em outras palavras: será racionalmente fundamentada e legítima toda a decisão que contenha a devida e correta fundamentação. Fundamentação, assim, que não tem importância apenas no campo técnico do direito (lei formal), mas possui relevância para obtenção de um ato jurídico válido. Como já diria Lênio Streck e Rafael Oliveira (2012, p. 99), "não há princípios constitucionais que resista à falta de fundamentação".

Em um sentido mais desmembrado pode-se dizer que a fundamentação é uma circunstância "em que se procura dar as razões por que se fez ou se determinou a feitura de qualquer coisa. É a apresentação dos motivos, que determinam a medida, que provocaram a solução, ou que possam justificar a pretensão" (SILVA, 1997, p. 547). Corroborando tal entendimento, Lênio Streck e Gilmar Mendes $(2013,1324)$ definem que as decisões judiciais “devem exteriorizar os elementos de juízo que a embasaram”.

Verifica-se que a fundamentação engloba uma série de circunstâncias importantes para validação da sentença, bem como citado supra, a fundamentação é determinante e justificativa dos atos jurídicos.

A evolução da humanidade demonstra várias distorções no que cabe a fundamentação das sentenças, desde a época que não era necessário fundamentar as decisões (final do século XVII) - a fundamentação só se tornou obrigatória com o advento de uma Lei de Organização Judiciária de 1810, na França (PORTANOVA, 2003, p. 248) - até os dias de hoje - Tribunal Europeu de Direitos Humanos considera a motivação (parte integrante da fundamentação) um direito fundamental a um processo equitativo (MENDES e STRECK, 2013, p. 1324) -, que na maioria dos casos podem ser consideradas nulas por serem imotivadas sobre os fatos da lide. 
O artigo 93, inciso IX da Constituição Federal de 1988 dispõe que "todos os julgamentos dos órgãos do Poder Judiciário serão públicos, e fundamentadas todas as decisões, sob pena de nulidade...”. Assim, por exemplo, ao condenar alguém em alguma obrigação o juiz estaria lhe restringindo direitos e para que tal ato fosse justificado na ordem jurídica pátria, deveria conter a devida fundamentação desse ato, por atenção ao direito fundamental ao devido processo legal. Essa concepção foi positivada no artigo $5^{\circ}$, inciso LIV da Constituição Federal de 1988 dispondo que "ninguém será privado da liberdade, ou de seus bens sem o devido processo legal." No momento que restringe algum direito ou impõe alguma obrigação, o magistrado deve fundamentar "como num levantamento topográfico, o itinerante lógico que percorreu para chegar a sua conclusão, pois se esta é errada, pode facilmente encontrar-se, através dos fundamentos em que altura do caminho o Magistrado se desorientou." (ALEXY, 2005, p. 05), ou seja, a essência das sentenças não deve mais ser verificada pelo antigo "aforisma de que a "sentença vem de sentire", sendo que a filosofia da consciência já foi superada (MENDES e STRECK, 2013, p. 1324).

Além disso, o Direito consiste em harmonizar as desavenças trazidas ao Poder Judiciário, pelo menos naquilo que se refere ao âmbito patrimonial das partes. Parece, portanto, como pensa Baptista, que o Direito não é apenas a dúvida entre o probo e o ímprobo, mas sim, o correto que deve ser feito. Nesse sentido, afirma o autor que o Direito deve oferecer os instrumentos e todas as condições concretas para que possam contribuir para realização de uma sociedade que se aproxime de um ideal de Justiça; não de uma sociedade “certa” (BAPTISTA da SILVA, 2006, p. 12).

Para tanto, é através da fundamentação que observa o caso concreto, personalíssimo, que cada decisão poderá ser considerada fundamentada. Assim, somente mediante os fundamentos "nela consignados - nas sentenças - que a comunidade jurídica pode (e deve) fazer a devida censura significativa principalmente naquelas decisões de natureza terminativa" (STRECK e OLIVEIRA, 2012, p. 97).

A lei, por muitas vezes, possui um caráter de ambiguidade, que possibilita a interpretação de várias formas. Embora participe da interpretação, o juiz deve apresentar que a 


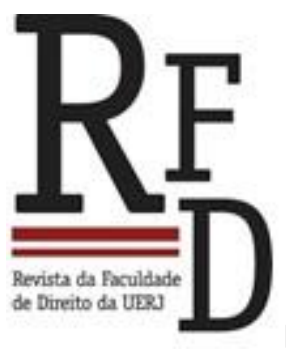

REVISTA DA FACULDADE DE DIREITO DA UERJ- RFD, N. 27, 2015

sua proposta se ajusta ao Direito vigente. Portanto, quando o magistrado fundamenta a decisão, dá azo para que outros intérpretes possam identificar qual o critério jurídico que dá suporte à decisão proferida. Não basta, apenas, "jogar” um artigo na decisão e não explicar por que foi usado este. Nesse sentido, a decisão deve ser minuciosamente abordada, devendo ser construída a partir do conjunto de fatos juridicamente valorados. Cada lide é uma lide, e cada decisão deve ser fundada de uma forma personalíssima.

Algo que deveria ser considerado errôneo e impertinente à justiça seria o fato das decisões do Tribunal do Júri e as hipóteses de julgamento sem apreciação do mérito (art. 469, segunda parte) dispensarem requisitos de fundamentação lógica.

Em que pese haver dispensa nos casos relatados supra, o magistrado está servido de conceitos indeterminados na lei, conceitos esses que o legislador não especificou de forma detalhada suas hipóteses de incidência ou exaurimento do comando a ser extraído da lei, cabendo ao julgador o papel de preencher as lacunas deixadas pelo legislador - de forma limitada e discricionária - com certa valoração subjetiva (BARROSO, 2011, p. 336).

Cita Barroso (2011, p. 336), que nossa Constituição está repleta de conceitos indeterminados, sendo eles: "pluralismo político, desenvolvimento nacional, segurança pública, interesse público, interesse social, relevância e urgência, propriedade produtiva”. Embora seja comum ouvir esse tipo de argumento, o juiz, quando decide em casos considerados indeterminados, não está dispensado de fundamentar o seu posicionamento.

É necessária, também, a explicação que apresenta a relevância às circunstâncias do caso concreto, ou seja, que os fatos sejam devidamente conhecidos e apresentados. Somente dessa maneira a prova dos fatos, considerada hábil a formar o convencimento do juiz, pode ser devidamente justificada. João Batista Lopes também relaciona a fundamentação judicial com a persuasão racional ou livre conviç̧ão motivada, entretanto, o juiz não pode julgar apenas baseado exclusivamente em suas emoções e impressões pessoais sobre o fato, visto que quando da apreciação das provas e sua interpretação deve ser indicada por meio da fundamentação, indicando como formou sua convicção de base constitucional (LOPES, 2005, p. 57). 


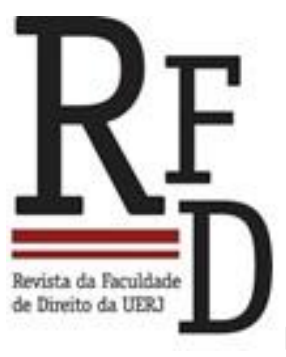

REVISTA DA FACULDADE DE DIREITO DA UERJ- RFD, N. 27, 2015

Não se pode negar que os fatos também precisam ser interpretados. Ao interpretar um "fato" e decidir por qual caminho irá seguir, o juiz deve tomar para si apenas as questões abordadas nos autos, não criando fatos novos e nem deixando de examinar os já constantes, conforme artigo 131 do Código de Processo Civil.

Quando tratar de sentença e fundamentação, há duas exigências que são impostas aos julgadores e que devem ser obrigatoriamente obedecidas para se dizer que a sentença está fundamentada por completo. É nesse sentido que Ovídio A. Baptista da Silva apresenta as condições necessárias da sentença, indicando que a primeira condição é uma persuasão racional, formando seu convencimento a partir dos fatos e circunstância constantes nos autos; após, deve explicitar seu convencimento através da análise crítica do conjunto de provas justificando, por uma intepretação fundada na Constituição, qual foi sua decisão (BAPTISTA da SILVA, 2006, p. 18).

Conforme acima exposto, a fundamentação das decisões judiciais é a resposta válida para a concretização do Direito, cujo é uma " "resposta culturalmente humana" ao problema também humano "da convivência no mesmo mundo e num certo espaço histórico-social"” (ESPINDOLA, 2013, p. 253).

A fundamentação da decisão judicial serve, pelo menos, a dois principais propósitos, quais sejam: um social e outro estritamente jurídico. Ou seja, quando a decisão é fundamentada, ela servirá de expressão à sociedade de como o direito responde a determinado problema. Ela servirá para guiar as condutas futuras na sociedade. Por outro lado, a fundamentação se mostra como uma exigência jurídica para que a decisão esteja de acordo com os ditames requeridos pelo Estado Democrático de Direito Assim, por exemplo, uma decisão que não contenha a devida fundamentação, ou, ainda, tenha uma fundamentação deficiente, não pode ser considerada como válida juridicamente. Existem dois princípios centrais que conformam uma decisão: a integridade e a coerência. São essas que caracterizam, ou não, a legitimidade da decisão (MENDES e STRECK, 2013, p. 1325).

Não é por menos que a sentença é a parte mais esperada do processo, porquanto é nela que se constitui de fato o que se tem direito. De acordo com José Naúfel (1989, p. 807) "é a 


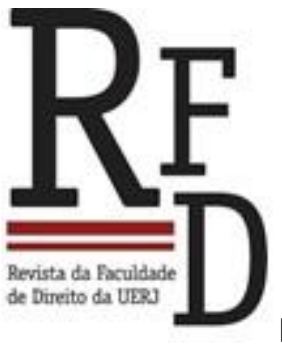

REVISTA DA FACULDADE DE DIREITO DA UERJ- RFD, N. 27, 2015

decisão que resolve a causa ou questão controvertida sobre a relação de direito litigioso", na qual considera uma das partes detentora de um título, mas nunca esquecendo que essa sentença deve ter seus fundamentos explicitados.

Ademais, em seu livro de Direito Constitucional, Daniel Mitidiero (2012, p. 668), reafirmam um ideal de que a fundamentação não está apenas ligada ao caso concreto, estando, além disso, justificando o exercício do poder e contribuindo para a evolução do direito, sendo necessariamente ultrapartes. Além disso, os autores traçam uma articulação mínima para validação constitucional da decisão:

(a) enunciação das escolhas desenvolvidas pelo órgão judicial para; (a1) individualização das normas aplicáveis; (a2) acertamento das alegações de fato; (a3) qualificação jurídica do suporte fático; (a4) consequência jurídica decorrente da qualificação jurídica do fato; (b) o contexto dos nexos de implicação e coerência ente tais enunciados e (c) a justificação dos enunciados com base em critérios que evidenciam ter a escolha do juiz ter sido racionalmente correta.

Nas palavras de Lênio Streck, temos que a noção de Estado Democrático de Direito está, "indissociavelmente ligada à realização dos direitos fundamentais", cujo agrega à construção das condições de possibilidades para suprir as lacunas das etapas de Estado anteriores, representadas pela necessidade do resgate das promessas da modernidade, tais como a igualdade, a justiça social e a garantia dos direitos humanos fundamentais (STRECK e OLIVEIRA, 2012, p. 128), visto que a necessidade de fundamentação das decisões judiciais decorre de um problema central da teoria do direito: a impossibilidade de previsão da lei sobre todos os fatos (MENDES e STRECK, 2013, p. 1324).

A sentença guarda relação com o princípio do contraditório porque é a partir dela que as partes terão o conhecimento de seus direitos e deveres, sendo que, ao proporcionar o princípio do contraditório, intrinsecamente, deve-se observar a obrigatoriedade do dever de fundamentação das sentenças e acórdão, pelo motivo que as partes têm total direito de obter a devida fundamentação sobre o que foi exaltado no decorrer do processo, ou seja, a ausência de fundamentação acarreta nulidade da sentença. 


\section{CONSIDERAÇÕES FINAIS}

Entende-se que esse tema é importante porque as decisões judiciais servem como espelho da observância dos preceitos fundamentais da dignidade da pessoa humana pelo Estado, haja vista ser a jurisdição órgão essencial para concretização intencional da democracia.

A velha concepção de que o Direito corresponde ao produto da legislação está superada pelo reconhecimento da importância do Poder Judiciário como órgão concretizador e garantidor de direitos.

Reconhecendo a suma importância da jurisdição na realização da democracia - em sua larga escala e essência - não se pode tolerar que ela, por meio de seus magistrados, suprima a fundamentação e não pratiquem o princípio da publicidade das decisões.

Deve privar a jurisdição - na condição de instituição indispensável à prática de um autêntico regime democrático, fundada em valores e princípio constitucionais, capacitadora da emancipação cultural, política, social e jurídica - a excelência e completude da sustentabilidade.

Entende-se, nesse diapasão, que a jurisdição é indispensável à democracia, visto que a contemplação dos direitos fundamentais e os valores constitucionais, como, por exemplo: a ampla defesa, o contraditório, o verdadeiro acesso à justiça, o devido processo legal, a publicidade dos atos da jurisdição, entre outros. Ou seja, apenas quando devidamente fundamentada as decisões judicias poderá ser alcançado esses princípios na sua essência.

Ocorre que, atualmente, o sistema jurisdicional, tanto no seu cunho material quanto processual, encontra-se em uma profunda regressão dos direitos sociais e fundamentais, visto que o sistema de justiça está em uma transação paradigmática do positivismo, haja vista não ser mais suficiente para sanar os questionamentos atuais.

A jurisdição, como peça chave da democracia, não pode ser falha muito menos ineficaz, caso seja, (in)diretamente estará afetando negativamente a democracia em seu contexto axiológico, e consequentemente não estará consolidando o que se espera do Estado 


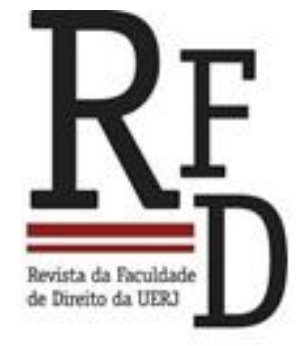

REVISTA DA FACULDADE DE DIREITO DA UERJ- RFD, N. 27, 2015

Democrático de Direito, por ser seu elemento principal. É na evidência da não existência dicotômica procedimental de hard cases e easy cases - partindo da superação do modelo sujeito-objeto por via do giro ontológico-linguístico - que o Constitucionalismo Contemporâneo, na essência do Estado Democrático de Direito, busca combater a figura do juiz solipsista , cujo tem como maior questionamento "o que devo fazer?" ao invés de "como deve ser feito?"

O juízo (julgador concreto-judicativo) deve usar os princípios constitucionais para valoração em uma forma de fechamento interpretativo (a partir da hermenêutica), conforme a época do fato concreto, devendo, também, fundamentar sua decisão de forma clara e completa, com meios de "responder" e sanar o presente litígio, haja vista a máxima filosófica de que todo cidadão tem "direito ao direito".

\section{REFERÊNCIAS}

ALEXY, Robert. Teoria da argumentação jurídica: a teoria do discurso racional como teoria da fundamentação jurídica. 2.ed., São Paulo: Landy Editora, 2005.

Teoria dos direitos fundamentais. Trad. Luis Virgílio Afonso da Slva. São Paulo: Malheros, 2008.

BARROSO, Luís Roberto. Curso de Direito Constitucional contemporâneo: os conceitos fundamentais e a construção do novo. 3. ed. São Paulo: Editora Saraiva, 2011.

BONAVIDES, Paulo. Curso de direito constitucional, 9. ed., São Paulo: Malheiros, 2000.

BRASIL. Constituição da República Federativa do Brasil, de 5 de outubro de 1988, Diário Oficial da União, Poder Legislativo, Brasília, DF, 5 out. 1988, p. 1, anexo. Disponível em: http://www.planalto.gov.br/ccivil_03/constituicao/constituicao.htm. Acesso em: 20 de jul. 2014.

CANOtilho, J.J. Gomes. Direito Constitucional e teoria da Constituição. 7. ed., Coimbra: Edições Almedina, 1997. 
; MENDES, Gilmar F.; SARLET, Ingo W.; STRECK, Lenio L. (Coords.). Comentários à Constituição do Brasil. São Paulo: Saraiva/Almedina, 2013.

DWORKIN, Ronald. Levando os direitos a sério. Tradução Nelson Boeira. $3^{\mathrm{a}}$ ed. São Paulo: Editora WMF Martins Fontes, 2010. Título original: Taking rights seriously.

ESPINDOLA, Angela Araújo da Silveira. Uma resposta culturalmente humana a um problema também humano: a crise da jurisdição e emergência do direito como plataforma civilizacional. In: TRINDADE, André Karam; ESPINDOLA, Angela Araújo da Silveira; BOFF, S. O (orgs.). Direito, Democracia e Sustentabilidade: Anuário do Programa de Pós-Graduação da Faculdade Meridional. Passo Fundo: Editora IMED, 2013, pag. 247280.

FERRAJOLI, Luigi. Constitucionalismo principialista e constitucionalismo garantista. In: ; STRECK, Lênio Luiz; TRINDADE, André Karam (orgs). Garantismo, hermenêutica e (neo)constitucionalismo: um debate com Luigi Ferrajoli. Porto Alegre: Livraria do Advogado, 2012, pag. 13-55.

HART, Herbert L.A. O Conceito de Direito. Lisboa: Fundação Calouste Gulbekian. $3^{\mathrm{a}}$ edição. 1994.

KARAM DE CHUEIRI, Vera. A dimensão jurídico-ética da razão: o liberalismo jurídico de Ronald Dworkin. In: ROCHA, Leonel Severo. Paradoxos da auto-observação: Percursos da Teoria Jurídica Contemporânea. 1 ed. Curitiba: JM Editora, 1997, p. 151-193.

KELSEN, Hans. Teoria pura do direito. Tradução João Baptista Machado. $6^{a}$ ed. São Paulo: Martins Fontes, 1988. Título Original: Reine Rechtslehre.

LOPES, João Batista. Curso de direito processual civil. parte geral. São Paulo: Atlas, 2005, v. 1.

MARINONI, Luiz Guilherme; MITIDIERO, Daniel. Código de Processo Civil comentado artigo por artigo. São Paulo: Editora Revista dos Tribunais, 2011.

MOURA, Elisabeth Maria de. O devido processo legal na Constituição Brasileira de 1988 e o Estado Democrático de Direito. São Paulo: Celso Bastos Editor, 2000.

NAÚFEL, José. Novo dicionário jurídico brasileiro. 8.ed. São Paulo: Ícone editora, 1989. 
NERY JUNIOR, Nelson. Princípios do Processo Civil na Constituição Federal. 7. ed. São Paulo: Editora Revista dos Tribunais, 2002.

PORTANOVA, Rui, Princípios do processo civil. 5. ed. Porto Alegre: Livraria do Advogado, 2003.

ROCHA, Leonel Severo. Paradoxos da auto-observação: Percursos da Teoria Jurídica Contemporânea. 1 ed. Curitiba: JM Editora, 1997.

SARLET, Ingo Wolfgang; MARINONI, Guilherme; MITIDIERO, Daniel. Curso de direito constitucional. São Paulo: Editora Revista dos Tribunais, 2012.

SCHMITT, Carl. Führung und hegemonie. In: Staat, Grossraum, Nomos. Editor Günter Maschke. Berlin: Duncker \& Humblot, 1995.

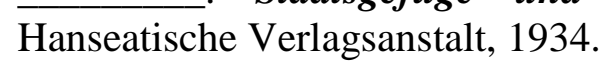

SILVA, De Plácido. Vocabulário Jurídico. Rio de Janeiro: Editora Florense, 1997

SILVA, José Afonso da. Curso de direito constitucional positivo. 26.ed. São Paulo: Malheiros Editores Ltda. 2005.

SILVA, Ovídio A. Baptista da. Fundamentação das sentenças como garantia constitucional. v. 1. in: Revista Magister de Direito Civil e Processual Civil. Porto Alegre, jan. 2006.

STRECK, Lenio Luiz. A hermenêutica filosófica de superação do positivismo pelo (neo)constitucionalismo. In: ; ROCHA, Leonel Severo (Org.). Constituição, Sistemas Sociais e Hermenêutica. Porto Alegre: Livraria do Advogado, 2005.

Hermenêutica Jurídica e(m) Crise. Uma exploração hermenêutica da construção do Direito. Porto Alegre. Livraria do Advogado. 2004.

. Jurisdição Constitucional e Hermenêutica. $3^{\text {a }}$. ed. Porto Alegre: Livraria dos Advogados Editora. 2013.

. O que é isto - decido conforme minha consciência?. 2 ed. Porto Alegre: Livraria do Advogado Editora, 2010.

Versão em português recebida em 03/12/2014, aceita em 21/04/2015, e autorizada para publicação em 29/06/2015 
; OLIVEIRA, Rafael Tomaz de. O que é isto - as garantias processuais penais? Porto Alegre: Livraria do Advogado Editora, 2012.

Verdade e consenso: constituição, hermenêutica e teorias discursivas. 5. ed., rev., mod e ampl. São Paulo: Saraiva. 2014.

TRINDADE, André Karam. Garantismo versus neoconstitucionalismo: os desafios do protagonismo judicial em terrae brasilis. In: FERRAJOLI, Luigi; STRECK, Lênio Luiz; (orgs). Garantismo, hermenêutica e (neo)constitucionalismo: um debate com

Luigi Ferrajoli. Porto Alegre: Livraria do Advogado, 2012, pag. 95-131. 